URPI SACO CHUNG ${ }^{1}$

\title{
Occupying and Expanding \\ (un)Expected Categories: Ways of Being and Becoming indigenous within the United Nations System²
}

\section{Introduction}

Today, in the international human rights arena, and especially at the United Nations (UN), it is no longer exceptional to see indigenous ${ }^{3}$ delegates at a meeting in Geneva or New York. In meetings such as the Conference of Parties (COP $\left.{ }^{4}\right)$ where climate change issues are discussed, the presence of indigenous people is expected. In the social sciences, as well as in other disciplines, we tend to associate indigenous peoples with narratives on climate change that relate to mining, resource extraction, neoliberal economics, and human rights. On the other hand, it is less common to see indigenous delegates making a statement during a session of the Human Rights Council, or at UN meetings where indigenous issues, as defined by the $\mathrm{UN}$, are not the main topic.

The example of the COP meetings partially illustrates how some categories or concepts are already occupied by ideas, meanings and practices about indigeneity,

\footnotetext{
${ }^{1}$ URPI SACO ChUNG is a PhD student in the Swiss Graduate Program on Anthropology, in the Graduate Institute, Switzerland.

${ }^{2}$ This article has been translated by Diego Silva and Philip Roberts. This article was originally published in http://www.alternautas.net/blog/2020/8/5/occupying-and-expanding-unexpectedcategories-ways-of-being-and-becoming-indigenous-within-the-united-nations-system

${ }^{3}$ In this text I will use 'delegates', indigenous delegates' and 'indigenous peoples' interchangeably.

${ }^{4}$ The Conference of the Parties (COP) is the supreme body of the United Nations Framework Convention on Climate Change.
} 
resource extraction and climate change. In particular, we can see how the aggregation and articulation of categories through ideas, practices, and meanings, create a narrative about what it means to 'be indigenous'. This abstract process is generated almost mechanically in our minds, but it is not neutral, it is a political process that is a constructed from particular stories, places, and power relations.

There are multiple answers to the question of what it means to be indigenous. This is a recurrent question in the scholarly debate on indigenous issues and in anthropological research in particular (Blaser 2014; Conklin, 1997; Hale \& Millamán 2005; Kuper 2003; Laurent 2016; Lucero 2006; Martinez Novo, 2006 among many others). The question of what it means to be indigenous generates controversies that I do not seek to resolve in this contribution. However, I think that through the study of indigenous participation within the UN system we can understand some of the complexities of these controversies, and the use in a particular context, of the category 'indigenous'.

This contribution is part of a project that seeks to understand the indigenous category through the participation of self-identified indigenous people in the context of several UN meetings. I will outline some unfinished reflections on how the analytical category 'indigenous' is represented within some spaces of the UN system. I will thereby explore how these representations fit with expected ideas of what it 'is to be indigenous' in these spaces, and how, through the observation of the performance of expected categories, the meanings of the indigenous category are expanded within a specific context and place.

I would like to mention that the reflections I present here have mainly been shaped by the epistemic meetings I have had with indigenous people during the last two years, but also by previous meetings. Although this reflective journey, as well as the meetings that I have had with these peoples, have enriched my reflections, I am fully responsible for the ideas that I present below.

This article is organized as follows: In the first section, I will describe briefly the spaces within the UN system where the indigenous delegates usually participate. In the second section, I will then describe in broad terms what procedures are followed within a UN session, and how the participation of indigenous delegates takes place. 
In the third section, I continue with an ethnographic observation of a participation of an indigenous delegate in the UN Human Rights Council. Finally, I end with some reflections on how we can continue to think about indigenous participation in bureaucratic spaces beyond the imposed and the expected.

\section{About encounters with and at the United Nations}

It is difficult to summarize the history of indigenous peoples' participation in international human rights spaces and the UN. There is an extensive scholarship on the international indigenous peoples' movement, the UN system, human rights, indigenous peoples' rights, the United Nations Declaration on the Rights of Indigenous Peoples (UNDRIP) and the multiple indigenous movements in Latin America and the Caribbean (Blaser; 2009; Dahl; 2012; Kenrick and Lewis, 2004; Lucero, 2006; Minde, 2008; Morin, 2012; Schulte-Tenckhoff, 1997, 2016; Schulte-Tenckhoff and Khan 2011, Stamatopoulou, 1994, inter alia). Throughout the history of international human rights bodies, the international indigenous movement has achieved visibility through many events and circumstances. The UN system is one of the platforms in the international arena where indigenous peoples participate, although it is not the only one. Indigenous peoples present a wide range of collective issues and demands in the different bodies of the UN. Since the late 1970s, the international presence of the indigenous movement has become prominent at the UN level, mainly due to the active participation of indigenous peoples and the creation of various mechanisms that address indigenous issues.

The UN human rights system in conjunction with the participation of indigenous delegates has created spaces, mechanisms and procedures, where indigenous issues are addressed. There, indigenous people organize, participate and have some degree of decision-making power. The Permanent Forum on Indigenous Issues (UNPFII), the Special Rapporteur on the Rights of Indigenous Peoples, and the Expert Mechanism on the Rights of Indigenous Peoples (EMRIP) are the three 
mechanisms established in the United Nations system that specifically deal with indigenous issues. ${ }^{5}$ Prior to the existence of these mechanisms, the Working Group on Indigenous Populations (WGIP), and the Working Group on the Draft Declaration (WGDD) were two important bodies that produced important milestones and institutional practices in the history of indigenous peoples within the UN. Indigenous delegates, UN staff and State representatives have participated in the drafting of important documents such as the United Nations Declaration on the Rights of Indigenous Peoples (UNDRIP). They continue to write updates, studies, and alternative reports for different UN bodies.

Within the UN, there are spaces of indigenous participation in addition to the mechanisms dealing solely with indigenous issues and the production of documents. The Office of the High Commissioner for Human Rights (OHCHR) in Geneva, within its Indigenous Peoples and Minorities Section (IPMS), has two important institutional structures that specifically promote indigenous participation in the UN. The Indigenous Fellowship Programme (IFP), and the United Nations Voluntary Fund for Indigenous Populations (UNVFIP). These two budget-holding structures play an important role in promoting one kind of indigenous participation in the UN system. However, these are not the only relevant structures in the United Nations. Other international organizations and agencies working on indigenous peoples' issues have their own fellowships and internships, for example the World Intellectual Property Organization (WIPO), and the International Labour Organization (ILO), among others. Currently, indigenous peoples usually participate in these UN mechanisms as delegates sent by their communities, as representatives of indigenous organizations and NGOs, as UN staff, and as official government representatives of their nation states.

\section{About being and/or becoming indigenous in and for the United Nations}

\footnotetext{
${ }^{5}$ These three mechanisms address indigenous issues and are mainly led by indigenous people working within the UN system.
} 
Indigenous delegates participating in the UN system are generally elected by their communities. For many of them, exposure to this international space implies changes to their personal lives, and changes for the lives of their communities. Most of the indigenous delegates I spoke with agreed that it is necessary to participate in the international arena to make their peoples and their situations visible, 'it is a way of showing that we have problems', 'if you do not come, they think everything is fine in your territory', 'we come to put pressure on them'. ${ }^{6}$ In some cases, their claims could benefit from international attention and international pressure. In some cases, this attention can lead to international tribunals's rullings.

During my ethnographic work, I observed several UN mechanisms, attended their meetings, and their sessions in Geneva and New York, where indigenous people participated. They usually participate by making statements and in describing the circumstances in which they live. In general, it is necessary to be accredited in order to participate in most UN meetings. ${ }^{7}$. This means that indigenous delegates have to be part of, or invited by, an organization that has a consultative status at the UN Economic and Social Council (ECOSOC). ${ }^{8}$ Getting this accreditation entails a process of registration, application and acceptance. This is a laborious and timeconsuming process. Indigenous individuals come to these meetings by different means, often supported (economically) by their communities, by grassroots organizations, through NGOs (local, national, international) that work in their territory or on a particular related issue (land grabbing, mining, climate change, water, education, etc.), with the government of the nation-state where their territories are located, invited by the UN, invited by universities, as specialists, lawyers, etc.

\footnotetext{
${ }^{6}$ These are extracts from informal conversations that I had with indigenous people in Geneva and New York (2016-2019).

${ }^{7}$ For example, the sessions of the Human Rights Council, the Universal Periodic Reviews (UPR), the Committee on the Elimination of Racial Discrimination, the Committee on the Rights of the Child, etc.

${ }^{8}$ See: https://csonet.org/index.php?menu $=34$
} 
The participation of indigenous representatives in the UN meetings usually consist of presenting data from alternative reports, acting as panelists or making statements (which is the most common way of participating). During a meeting, indigenous representatives make statements on different issues, such as: struggles in their territories, violation of human rights and the Declaration on the Rights of Indigenous Peoples, etc. They also organize side events. In addition to this, during their visits to any of the UN headquarters, they organize meetings with the staff of UN committees and conventions and with their countries' official representatives to the UN (permanent missions, embassies, etc.). They also network with other local and international organizations and NGOs.

The Human Rights Council (HRC) offers an example of indigenous peoples' participation in the UN. This intergovernmental human rights body meets regularly in Geneva, three times a year. A panel discussion on the Rights of Indigenous Peoples is scheduled during the last of these sessions, which takes place in September. As in many UN sessions, one of the ways in which attendants participate is by making a two to three-minute statement. Clearly, the content of those statements is influenced and delimited by time constraints. We could broadly summarize the structure of a statements as follows (whether the are given by indigenous or non-indigenous participants): Acknowledgments and greetings to the chair of the session and/or the panelists, brief presentation of a situation (preferably) related to the topic addressed during the panel, and conclusions, accompanied by some requests, suggestions, and recommendations to improve the aforementioned situation. A statement is expressed (mainly read) in one of the official languages of the UN (English, French, Spanish, Russian, Chinese, Arabic) and it is simultaneously interpreted.

There are some additional logistical procedures that must be completed in order to make a statement during a HRC session. As mentioned above, the organization facilitating the participation of the indigenous delegate needs to be accredited by ECOSOC. This will allow the session participants to acquire UN badges to enter the facilities where the meeting will take place. The person who is going to make a statement should previously register online to the list of speakers, and print and give copies of his/her statement to the HRC secretariat to facilitate the work of the 
interpreters, etc. The speaker will only take the floor if time allows. Many times sessions are lengthy, which reduces the time to deliver statements. In those cases the list of speakers will be shortened and only those at the top of the list will participate. From this description I argue that by (trying to) make a statement, an indigenous delegate in the HRC embodies and represents UN practices and knowledges. He or she temporarily incorporates and enacts the codes of the UN.

How are these codes known, incorporated, and enacted by indigenous representatives? According to my observations, indigenous people know how to represent and use these codes. They seem to know them by being there. They understand them without necessarily fully knowing the whole dynamic of a HRC session. Moreover, they have been informed about these codes by their hosts in Geneva or partners in their home country. However, knowing the protocol and putting it into practice are two different things. In my conversations with them, some indigenous people recognized to have felt nervous when they made a statement for the first time at the UN. Those who had had a previous experience delivering statements felt more comfortable when giving a statement for the second or third time. Others felt familiar with the UN dynamics, since they had been participating in these meetings for many years. After participating in a UN session for the first-time things become easier. The practice of giving a statement becomes an acquired and embodied knowledge.

There are various channels through which participants (indigenous and nonindigenous) can learn and become familiar with the protocol of a UN meeting, as well as with indigenous rights issues and mechanisms of participation in the international arena, etc., Some examples include the indigenous peoples' fellowship programme (organized by the $\mathrm{OHCHR}$ ), international human rights training programs, university diplomas in indigenous rights, etc.

After this brief description of how indigenous individuals participate in a HRC session (this format is repeated in many sessions of other UN mechanisms; there are also other forms of participation), we can argue that in such moments and spaces 
different (at least more than two) epistemologies converge. For example, Mapuche, indigenous, urban, and international epistemologies. Some Mapuche people know how to be and act in their Mapuche world. ${ }^{9}$ They also know the international indigenous movement and the urban environment of their country of residence. Moreover, they know how to enact the international codes of being and doing in the UN. They know how to be indigenous in the UN. However, they are still Mapuche and they are constantly (re)creating and rethinking their indigeneity internally, in front of other Mapuches, and in front of indigenous and nonindigenous people. In contrast, the UN does not know about the Mapuche ways of being and doing.

\section{Encounters: the expected indigenous people?}

As mentioned before, indigenous people encounter and interact with different knowledges in the UN. They (like all people) may not consciouslly realize that they do so all the time, since encounters occur almost spontaneously. This, however, does not mean that these encounters are not tense, disruptive and conflictive moments. Since the procedures for participating in the UN are quite structured, these encounters involve effort, energy, intuition, the ability to relate quickly with codes, and to understand the some functioning logics.

We can understand a particular type of participation in the UN (such as making a statement) as an embodied enactement of multiple knowledges. Making a declaration in the UN is a representation of the UN discourse and practices intertwined with indigenous practices and knowledges (the use of indigenous languages at the beginning and end of the declaration, practices, logics and ways of describing an event, body language, etc., that belong to indigenous epistemologies).

\footnotetext{
${ }^{9}$ Similarly, in a specific Mapuche or indigenous world, one can live in different ways, as a child, a woman, a man, an elder, a shaman, a widow, an indigenous intellectual, etc. It is important to highlight the heterogeneous ways in which indigenous people live their lives in their territories and also to mention that there are many shared codes and others in dispute.
} 
These entangled ways of doing things are also informed by the need to mobilize useful knowledge according to the situation, time, place and context in which the statement is given.

When I address this type of encounters in my observations, I explore what I call 'the expected indigenous' and the meanings that such category has in the UN. I referred earlier to how in the social sciences we use categories to explain and partially describe the sociality of our daily lives. It is worth mentioning again that, in giving meaning to a category, this category becomes delimited. Clearly, we use categories that have already been given a meaning in order to be able to begin any type of analysis about any issue. However, as our analysis advances, we recognize the limits of our categories, we realize that these can be flexible, elastic, and that they usually go beyond the meaning that we had momentarily given to them. We need to acknowledge that categories and meanings are in motion, have nuances, and can potentially challenge knowledge hierarchies.

Often in the UN environment, indigenous people are expected to be indigenous in many ways - in ways that they know and in ways that they do not know a priori. There is an expectation of what it means to be indigenous in general, of what it means to be indigenous in the UN, and of how to fit into that category. The fulfillment of these expectations is necessary in order for indigenous delegates to be able to participate in the UN.

The meanings associated with the indigenous category can be related to political positions, to practices, to origins and land, to strategies, to performativity, to being part of the UN, but above all, they are related to self-determination, and to being recognized as a member of a people and community. Generally, the people we call indigenous identify themselves discursively by saying 'I am Quechua', 'I am Awajún', 'I am Mapuche' before identifying themselves as indigenous. ${ }^{10}$. The category is, a priori, occupied by a plurality of discursive meanings and is enacted in

\footnotetext{
${ }^{10}$ In this contribution I consciously use the homogenizing and institutionalized character of the 'indigenous' category since I will not develop, in depth, any specific case of an indigenous people or person.
} 
multiple ways. That is to say, it is incessantly recreated by indigenous and nonindigenous people, it is not permanent, and it exists in relation to, or vis-a-vis, its interlocutors.

There have been several attempts to define indigenous peoples in the UN. Today, a working definition is used. It was elaborated as a legal and political category. This definition includes four criteria: indigenous peoples are not dominant in economic, political and socio-cultural terms, although they are not necessarily always a minority in numerical terms; they are the descendants of the inhabitants of a given territory; they have been victims of genocide, conquest, and colonization; and they seek to maintain their identity. This working definition is useful to some extent and can be adapted to most indigenous peoples who have sufferd from processes of colonization. However, this definition does not fit all peoples who consider themselves indigenous. Moreover, there are controversies about these definitions, about the indigenous category and about the notion of indigeneity (SchulteTenckhoff, 2012). Despite this, mentioning the UN definition is useful here because it allows an (initial) understanding of how indigenous peoples are perceived (as a category) within the UN system.

In order to broaden our understanding of the 'indigenous' category in the UN environment, it is important to avoid adopting static definitions. However, we do recognize that there is a collective and almost ubiquitous idea of what it means to 'be indigenous' in general (an idea that must be challenged tirelessly). This expectation has been created through many historical processes, research, the media, etc. According to my ethnographic notes, the expected idea of being indigenous in the UN is broader and more ambitious than the working definition mentioned above. Being indigenous in the UN implies, in addition to working definition's criteria, living in an indigenous territory, being recognized by their people, advocating for indigenous and human rights, being recognized as a leader in their communities, speaking a UN language, having participated in other international or regional human rights bodies, among other requirements. These are some of the expected characteristics that an indigenous person should have (or be acquiring) when participating in a UN meeting. In addition to this, it appears to be important 
for them to speak an indigenous language, to wear their traditional dress, and to know or perform traditional practices.

Therefore, in order to actively participate in a UN session, an indigenous person is required to meet all of these (and other) expectations. To simultaneously perform and embody all of these discourses and practices is a very difficult task, yet indigenous persons manage to do so. In performing the 'expected indigenous person', indigenous people in the UN carry out practices and discourses that go beyond these expectations. They perform what is expected from them and much more. The unexpected. In a HRC session, indigenous people must be flexible enough to adapt to meeting formats and differentiated ways of doing things. The codes of participation in an indigenous territory may follow different formats, although similar practices and epistemologies might also be found there. However, some practices have been historically more valorized in non-indigenous settings while others are not taken seriously. This situation highlights the challenges that are faced by indigenous leaders when acting between different forms of knowledges, values and epistemic hierarchies, and when enacting what is expected from them by indigenous and non-indigenous interlocutors. It is important to say that there are also expectations among indigenous peoples from the same community, and expectations between peoples from different communities. These encounters often require the embodiment of non-indigenous knowledges in order to protect an expected indigenous indentity.

\section{Between the expected and the unexpected: observations of a statement in the Human Rights Council}

I will now present some reflections on the observation of a statement made by an indigenous woman during a session of the HRC. Through this observation I attempt to broaden the understanding of the indigenous category, and to challenge its homogenizing limitations, within a specific space of the UN system. That is, I attempt to show how our analytical categories are loaded with (un)expected meanings that we need to make visible. 
On the $19^{\text {th }}$ of September 2018, during the twentieth session of the 39th regular session of the Human Rights Council, a panel discussion was held on the inclusion of indigenous peoples in Agenda 2030. Each year the HRC organizes a panel discussion, usually lasting half a day, specifically related to the rights of indigenous peoples. During this particular session, the intervention of an indigenous delegate made me question and reconsider what I consider to be an (un)expected category.

After having observed multiple meetings and sessions related to indigenous issues at the United Nations in Geneva, New York, and at the UN website, I had become used to the 'prefabricated' type of statement described above. I had internalized that format as 'normal', as it is also likely to be internalized by the indigenous and nonindigenous peoples who attend and participate in these spaces. Observing a particular practice repeatedly can be counterproductive. It can become a weakness that we face as researchers when we are exposed to ethnographic experiences that seem to be similar. It is a weakness because it predisposes us not to listen to what is not said, not to look beyond what we see. I had been seeing and hearing what was expected, without allowing myself to perceive what was (un)expected. I had limited my observation sensibility in my own ethnographic experiences.

During the aforementioned panel in Geneva, an indigenous woman representing the Guarani-Kaoiwá people from Matto Grosso do Sul, Brazil, made a statement that was (un)expected for me. The almost three minutes of her statement seemed longer and more complex than usual. If my intuition does not betray me, I believe that this did not go unnoticed for the people who were present in room XX of the Palais des Nations in Geneva. ${ }^{11}$

Here is a brief description of this participation. The Guarani-Kaoiwá woman began reading her statement in Spanish. She read it slowly and with difficulty. Usually the

\footnotetext{
11 See this particular intervention in the followin link (minute: 1:32:55 - 1:25:39) http://webtv.un.org/search/panel-discussion-on-inclusion-of-indigenous-people-in-2030agenda-20th-meeting-39th-regular-session-human-rights-council/5836878420001/?term=indigenous\%20panel\%20HRC\&cat=Human\%20Rights\%20Council\&sor $\mathrm{t}=$ date\&lan=original
} 
speakers (indigenous and non-indigenous) read their statements quickly because there is not enough time to mention all they want to say. The speakers who preceded and followed this woman's statement read their statments in the expected way. However, when she began her participation, a tension was felt across the room, at least for a couple of minutes. I had heard that reading slowly could be a strategy used to get the full attention of the room. However, this did not seem to be her intention in this case. The woman read her text in Spanish for about two minutes and then she switched from Spanish to Portuguese (for one minute). During this time she didn't read, but spoke.

Spanish was not a language in which the speaker felt comfortable. She did not master this language as a native Spanish-speaking person. Spanish was a foreign language to her. The situation changed when she spoke in Portuguese since this is the official language of her country of residence. Portuguese may be the first, second or third language she speaks. Her mother tongue may be an indigenous language or Portuguese. Let us not forget that Portuguese is not an official language of the United Nations. Therefore, the simultaneous interpretation that accompanied her presentation, and the subtitles that accompany the video recording of this presentation, are not completely faithful to what she said in Portuguese.

As a spectator, I was expecting a quick reading of her statement. This is an institutionalized practice that is recommended and suggested in the United Nations. It is part of the ways of doing in the UN. I was waiting for the expected indigenous person who fits into the category of indigenous in the UN. The Guarani-Kaoiwá woman reading the statement was partially performing this category. However, she did not seem comfortable in this language, or at least reading in it. Things changed when she switched to Portuguese. She was able to express her ideas and emotions more fluently. This situation triggered me and made me reflect on the fact that Portuguese is not one of the languages that is interpreted in UN meetings; that reading in Spanish as a skill, and what is involved in accessing 
and mastering this skill; and even thinking about the lack of necessity, use, and value of this skill for some persons that do not use it on a daily basis. ${ }^{12}$ At this point I thought that the UN system only listens to those who enact its codes and speak its recognized languages. The indigenous person spoke in a UN language when reading the text. Then, when she changed to Portuguese it proved to be a challenge for the UN interpretes. She was no longer speaking one of the UN official languages. However, it was more comfortable for the speaker to say what she had come to say. Broadly speaking she said: '...that she was bringing her pain and that of her people to the UN... and that she needs help from the UN... because her people are suffering a lot... and she asks the president of the UN to speak to the president of Brazil so that the latter pays more attention to indigenous peoples' (my translation and interpretation).

Beyond the use of different languages and the headdress that she was wearing, which is distinctive and traditional of her indigenous community, her reading and her speaking reveals many complexities and tensions. The text she read in Spanish mentioned the objectives of the 2030 agenda. It was a text that had been prepared following a 'UN' theme. When she spoke in Portuguese, the tone of her speech was different. It was shaped by statements asking for attention to the particular situation of her people within their national framework. The statement became, perhaps, less loyal to protocol, but it was loaded with emotions and its message was more direct.

The multiplicity and complexity of her statement, and its enactment within the rigidity of a protocolary space, continues to catch my attention. This is not the first time that this has happened, nor will it be the last. The participation of this speaker was in line with the expected category of the indigenous in the UN. However, her participation revealed more than that. She was wearing a traditional headdress, she spoke about Agenda 2030, she spoke in two languages, and she briefly got the attention of the room. I imagine that when her participation ended, she had

\footnotetext{
${ }^{12}$ Which is related to the limited presence of the 'official' Brazilian state education system in indigenous territories, as well as to discrimination and inequality in access to education, among multiple other structural reasons related to standardized literacy.
} 
meetings and encounters with NGO representatives, with representatives of the Permanent Mission of Brazil to the United Nations, she probably walked around Geneva, returned to her community, saw her participation again on the Internet, continues to fight for her cause, is a mother, and leader in her community, etc.

\section{Openings: expanding (un)expected categories}

This contribution is part of a series of observations and reflections on indigenous participations within the UN system. The observation that was described in this contribution is one of them and I would like to make it clear that I have not spoken with the person in this example. However, her participation was crucial to my observations, especially when it comes to problematizing the expected category of an indigenous person in the $\mathrm{UN}$ and, in consequence, when it comes to destabilizing our narratives about the people who inhabit (to us) this category. In a certain way, this example points to the need of re-encountering excess - or humanity - within this (un)expected category. We are more than categories and definitions.

The participation of the Guarani-Kaiowá woman sent several messages in various codes and languages. The most explicit ones were the issues related to Agenda 2030 and her request to the UN president. More subtle messages were conveyed by her uncomfortable reading in Spanish and by her speech in Portuguese. She simultaneously fulfilled the expectations of the UN while giving us something unexpected: the obligation to hear to her discomfort while reading in Spanish. This unexpected moment makes visible the indigenous people that we refuse, or perhaps do not want, to see and hear, because they not know all the ways of doing in the UN (the official languages, for example).

I have reflected and thought about the UN meetings as hegemonic, colonial, and inflexible spaces of imposition and protocols. However, these are also idealized spaces that generate expectations in those who freely determined themselves as indigenous. This is becuase in these spaces indigenous peoples can make specific demands and requests. There, indigenous peoples can also continue to ask for 
official recognition from their states. Although it is unfortunate that they still have to do so. The UN embodies an ideal of an institution that defends human rights. Moreover, as mentioned at the beginning of this contribution, participating in the UN can shed light on urgent, and not so urgent, situations that indigenous peoples around the world have to face. Unfortunately, indigenous expectations and indigenous ways of doing things do not permeate the UN system, as do the practices and codes of the UN to the lives of those who participate in it. There have been improvements in the UN human rights bureaucracy, but these changes are not as rapid as the indigenous delegates' learning of the UN codes and ways of doing things.

Therefore, the use of fixed categories is useful, although just as a starting point to explain and analyze events and interactions, as well as the ordinary and the extraordinary within everyday life. Participating in a UN meeting involves multiple encounters of knowledges and epistemologies; encounters where a plurality of ways of doing and being, that characterize both the UN and indigenous people, are interrelated and coexist. These ways of doing and being are heterogeneous and should be understood as such. This diversity is performed through adaptation and contestation of what is expected (e.g. to comply with the UN protocols, to meet the community's expectations, etc.).

As it has been shown in this contibution through an ethnographic example, when a statement is made by an indigenous delegate it is possible to see them push at the boundaries of the (expected)indigenous category. This is a moment where different knowledges are enacted. The expected indigenous category is surpassed in practice and meaning. The indigenous participants in the UN adapt, appropriate, translate codes, interpret, embody, change and still remain indigenous (in their own way and to themselves). In addition to intertwining different types of knowledges in this process, they continuously co-constitute their identity. This process is rational, emotional, non-permanent, and contextual.

Indigenous people have a long history of involvement in the UN. This history must be read considering different perspectives, such as processes of colonization and decolonization, power relations, and political tensions, within and between member states, and the history of indigenous peoples' engagement and active participation 
in the UN, to name just a few. A thorough analysis of these complex processes will help us to better understand how heterogeneous the participation of indigenous peoples in the UN really is. This type of participation is relational, it considers the interconnectedness of different types of knowledges, and it can help to complexify the binary, hierarchical, and expected categorization of what it means to be 'indigenous and non-indigenous'.

The need to go beyond and to expand the meaning of different categories is evident and it is not a new debate. The argument presented in this contribution seeks to recognize how rich, diverse and fluid is the enactment of the (un)expected indigenous category, and how its expected meanings are exceedded. From this recognition, we can begin to expand the analysis and understanding of indigenous people's participation and enactment of indigeneity in international spaces, through ethnographic concepts (De la Cadena 2015) and ethnographic categories. This type of approach does not seek to create new categories or delimit existing ones, but rather, to contribute to improving our understanding of what it means to be indigenous in and for the UN today. In broadening our understandings of existing categories, we engage in a theoretical-political decolonizing project, and in the dehierarchization of meanings, knowledges and categories. This project involves provincializing (Chakrabarty, 2008) dominant epistemologies and moving towards a reconfiguration, at least in academia, of knowledge hierarchies, as well as moving towards epistemic justice (Santos, 2018). Moreover, this project demands a debate that goes beyond static definitions, that incorporates strategic essentialism (Spivak 1984), performativity (Conklin, 1997; Graham, 2002; Warren \& Jackson, 2002), and other concepts; concepts that allow us to continue expanding the discussion on indigeneities, on open definitions of indigenous identities and on constant processes of co-constitution of identity.

Finally, I would like this analysis to contribute to two sets of questions: how do we broaden the meaning of what it is to be indigenous for and in the UN system, and outside it as well; and how can we collectively rethink our methodologies, positionalities and reflexivities when we conduct research with indigenous peoples. I look forward to working with self-identify indigenous persons in types of research that are collaborative and non-extractivist, yet this contribution is still a limited 
Occupying and expanding (un)expected categories | 130

academic excercise. However, I hope to have at least provoked dialogue, openings and disagreements.

\section{References}

Blaser M. 1994. El emerger de otras voces: Discursos globales y textos locales. Runa, 21(1), 83-97.

Blaser, M. 2009. Political Ontology. Cultural Studies, 23(5-6), 873-896.

Blaser, M. 2014. Ontology and indigeneity: On the political ontology of heterogeneous assemblages. Cultural Geographies, 21(1), 49-58.

Blaser, M. 2016. Is Another Cosmopolitics possible? Cultural Anthropology, 31(4), 545-570.

Conklin, B. 1997. Body Paint, Feathers, and VCRs: Aesthetics and Authenticity in Amazonian Activism. American Ethnologist, 24(4), 711-737.

Dahl, J. 2012. The indigenous space and marginalized peoples in the United Nations (1st ed.). New York: Palgrave Macmillan.

De la Cadena M. 2005. The production of other knowledges and its tensions: from andeanist anthropology to Interculturalidad? Journal of the World Anthropology Network (1):3-33.

De la Cadena, M. 2010. Indigenous Cosmopolitics in the Andes: Conceptual Reflections beyond "Politics". Cultural Anthropology, 25(2), 334-370.

De la Cadena, M., 2015. Earth beings: Ecologies of practice across Andean worlds (The Lewis Henry Morgan Lectures 2011). Durham; London: Duke University Press.

De la Cadena, M. \& Mario Blaser (eds). 2018. A World of Many Worlds. Durham: Duke University Press. 
Escobar A. 2011. ¿ "Pachamánicos » versus « Modérnicos »? Tabula Rasa. Bogotá Colombia, No. 15: $265-273$.

Escobar A. 2014. Sentipensar con la tierra. Nuevas lecturas sobre desarrollo, territorio y diferencia. Medellín: Ediciones UNAULA, (Colección Pensamiento vivo).

Garcia M.E. 2005. Making indigenous citizens: identities, education, and multicultural development in Peru. Stanford university Press.

Graham L. 2002. How Should an Indian Speak? Brazilian Indians and the Symbolic Politics of Language Choice in the International Public Sphere. In: Indigenous Movements, Self-Representation and the State in latin America. Jean Jackson and Kay Waren, eds. Pp. 181-228. Austin: University of Texas Press.

Gupta, Akhil, and James Ferguson. 1997. Anthropological locations: boundaries and grounds of a field science. Berkeley, CA: University of California Press.

Hale C. \& Rosamel Millaman. 2005. Cultural Agency and Political Struggle in the Era of Indio Permitido. In: Cultural Agency in the Americas, edited by Doris Sommer. Durham, NC: Duke University Press. Pp. 281-304.

Holbraad, M., \& Pedersen, M. (2017). The ontological turn: An anthropological exposition. Cambridge: Cambridge University Press.

Ionita, I. 2015, Un itinéraire de recherche en terrain autochtone au Canada. L'empathie dans tous ses états. L'Harmattan, Paris.

Kenrick, J., \& Lewis, J. 2004. Indigenous Peoples' Rights and the Politics of the Term 'Indigenous'. Anthropology Today, 20(2), 4-9.

Kuper, A. 2003. The Return of the Native. Current Anthropology, 44(3), 389-402.

Laurent V., 2016. Élite(s) e indianidad en Colombia: retos de democracia en contexto de multiculturalismo. Colombia Internacional, Issue 87, pp. 145-169. 
Occupying and expanding (un)expected categories | 132

Leyva X., \& S. Speed. 2008. Hacia la investigación descolonizada: nuestra experiencia de co-labor. In: en Xochitl Leyva, Araceli Burguete y Shannon Speed (Coordinadoras), Gobernar (en) la diversidad: experiencias indígenas desde América Latina. Hacia la investigación de co-labor. México D.F., CIESAS, FLACSO Ecuador y FLACSO Guatemala, pp. 34-59.

Lucero, J. 2006. Representing "Real Indians": The Challenges of Indigenous Authenticity and Strategic Constructivism in Ecuador and Bolivia. Latin American Research Review, 41(2), 31-56.

Martínez Novo, C. 2006. Who defines indigenous?: Identities, development, intellectuals, and the state in northern Mexico. New Brunswick, N.J.: Rutgers University Press.

Minde, H., \& Jentoft, S. 2008. Indigenous peoples: Self-determination, knowledge, indigeneity. Delft: Eburon Delft.

Morin F. 2012. La Déclaration des Nations Unies sur les droits des peoples autochtones à l'épreuve du temps (2007 - 2012). Montréal. Cahier DIALOG $\mathrm{n}^{\circ} 2012-05$.

Quijano, A. 1999. Colonialidad del poder, cultura y conocimiento en América Latina. Dispositio, 24(51), 137-148.

Rivera Cusicanqui, S.; J. Domingues; A. Escobar \& E. Leff. 2016. Debates sobre el colonialismo intelectual y los dilemas de la teoria social latinoamericana. Cuadernos de Sociologia 14:1-32, numero especial editado por M. Svampa.

Santos, B. 2014. Epistemologies of the South: Justice against epistemicide. Boulder: Paradigm.

Santos B. 2018. The End of the Cognitive Empire. The Coming of Age of Epistmologies of the South. Durham: Duke University Press.

Schulte-Tenckhoff, I. 1997. La question des peuples autochtones (Axes. Bruylant 21). Bruxelles: Bruylant; Paris : L.G.D.J. 
Schulte-Tenckhoff I. \& Adil Hasan Khan. 2011. The permanent Quest for a Mandate. Griffith Law Review, 20 :3, 673-701.

Schulte-Tenckhoff I. 2012. Treaties, peoplehood and self-determination: understanding the language of indigenous rights. In: Indigenous Rights in the Age of the UN Declaration (E. Pulitano ed.), Cambridge University Press, p. 64-86.

Schulte-Tenckhoff, I. 2016. La Déclaration des Nations Unies Sur Les Droits Des Peuples Autochtones: Prétexte à Quelques Réflexions Sur Les Usages De La Diversité Culturelle. In: La diversité dans la gouvernance internationale: perspectives culturelles, écologiques et juridiques. - Bruxelles: Bruylant. p. 33-53.

Speed, S. 2008. Forged in Dialogue: Toward a Critically Engaged Activist Research. In Hale C. R., C., \& Calhoun, Craig. 2008) Engaging Contradictions. University of California Press.

Stamatopoulou, E. 1994. Indigenous Peoples and the United Nations: Human Rights as a Developing Dynamic. Human Rights Quarterly. Vol. 16, No. 1 pp. 5861.

Viveiros de Castro, E. 2004. "Perspectival Antrhopology and The Method of Controlled Equivocation, " Tipití: Journal of the Society for Anthropology of Lowland South America: Vol. 2: Iss. 1, Article 1.

Waren K. \& Jean Jackson (eds.). 2002. Indigenous Movements, SelfRepresentation and the State in Latin America. Austin: University of Texas Press. 